\title{
Forest Conversion in Upstream Oil and Gas Industry Area
}

\author{
Bayu Andrianto Wirawan, ${ }^{1}$ Meyzi Heriyanto ${ }^{2 *}$, Darwis, $\mathrm{AN}^{3}$ \\ ${ }^{1}$ Doctoral Program in Environmental Science, Universitas Riau, Pekanbaru, Indonesia \\ ${ }^{2}$ Department of Business Administration, Universitas Riau, Pekanbaru, Indonesia \\ ${ }^{3}$ Department of Marine Science, Universitas Riau, Pekanbaru, Indonesia \\ ${ }^{*}$ Corresponding author: \\ Email: meyzi.heriyanto@lecturer.unri.ac.id
}

\begin{abstract}
.
Forest conversion is the root of the problem that can hamper investment, state revenue, and potentially cause state losses. The purpose of this study was to analyze forest conversion in the upstream oil and gas industry area and the factors that influence forest conversion in the upstream oil and gas industry area based on spatial analysis. This study used systematic sampling with the point grid method measuring 1 kilometers * 1 kilometers. Rokan Block had 5,125 sampling points. This study used raster-based GIS analysis and logistic regression with the Wald Test. The results of the study showed that the Rokan Block Area experienced a fairly severe forest conversion in 2000-2014 influenced by the total population and The 1986 TGHK. The novelty of this study is that the active role of communities around the forests that still upholds the concern for the forest must be preserved, because they will be the front guard in securing forest encroachment, and upstream oil and gas industry are not the main economic activities that cause forest conversion.
\end{abstract}

Keywords: forest conversion, upstream oil and gas industry area

\section{INTRODUCTION}

The oil and gas industry is an important sector and contributed 66 percent of total non-tax revenue (PNBP) and absorbed a large workforce. $\left[{ }^{1}\right]$. Rokan Block Riau Province contributed 40 percent of national oil demand and 30 percent of regional income, $\left[^{2}\right]$, but there is an opinion that the upstream oil industry is one of the factors causing land-use change from forests to non-forests (forest conversion). Harun, $\left.{ }^{3}\right]$ stated that the upstream oil industry is one of the main causes of forest conversion in Riau. Harun also states that based on The 1986 TGHK to The 2014 Forest Area Policy, oil and gas are one of the causes of the forest conversion.

Wirawan and Hidayatsyah, $\left[{ }^{4}\right]$ state that 8,020 ha of the oil production plant in Rokan Block is still overlapping with new policies on forest area planning based on maps SK 878/2014 jo SK 903/2016 on Riau Province Forest Area by KLHK (Ministry of Environment and Forestry). The map from KLHK is one of the main maps used as sources for the preparation of the RTRW (Land Use Planning). Oil and gas assets are state property based on Minister of Finance Regulation No. 135/2009 jo Minister of Finance Regulation No. 165/2010 which must have a clear status. 
Land-use change in the implementation of development cannot be avoided. These changes occur because of two things, namely the need to meet the increasing needs of the population and increasing demands for a better quality of life. McNeil, [ $\left.{ }^{5}\right]$ stated that the driving factors of land-use change are politics, economics, demography, and culture. Land-use change is a reflection of human efforts in utilizing and managing land resources that have an influence on humans and environmental conditions.

The main foundation for the implementation of spatial use is the spatial planning document as legislation that binds the public and also government officials. However, spatial plans in Indonesia in the field are not implemented with the same level of discipline as zoning documents in the regulatory system. $\left.{ }^{6}\right]$. The purpose of this study was to analyze forest conversion in the upstream oil industry area and the factors that influence forest conversion in the upstream oil industry area with spatial analysis.

Spatial analysis is a quantitative method to see the diversity of things spatially. Geographic information system (GIS) is an automation system for handling spatial data. This system can encapsulate information intelligence geographically (spatial). In spatial modeling, there are two categories of area data structures namely vector and raster. Vector is a data structure based on coordinates and shapes such as points, lines or areas, while raster is a data structure based on cells, such as remote sensing satellite imagery data. $\left[^{7}\right]$

Spatial data is the illustration of objects in space. Objects in the space are classified into four types, namely points, lines, areas and surfaces. Attribute data can be shown by nominal, ordinal, interval and ratio scale. The absolute location of the space is defined in the $(\mathrm{x}, \mathrm{y})$ coordinate system independent of the object being mapped (Kraak and Ormeling, 2010)

\section{METHODS}

The population in this study was the total land area in the Rokan Block. Rokan Block has an area of $650,000 \mathrm{Ha}$. Data on these variables were processed in the form of grid/raster data. With a resolution of 30 meters * 30 meters per pixel. Sample selection was performed by using systematic sampling based on the method of a grid point by Jensen. $\left[{ }^{8}\right]$. The point used for the sample was 1 kilometers $* 1$ kilometers. The illustration of systematic sampling can be seen in Figure 1.

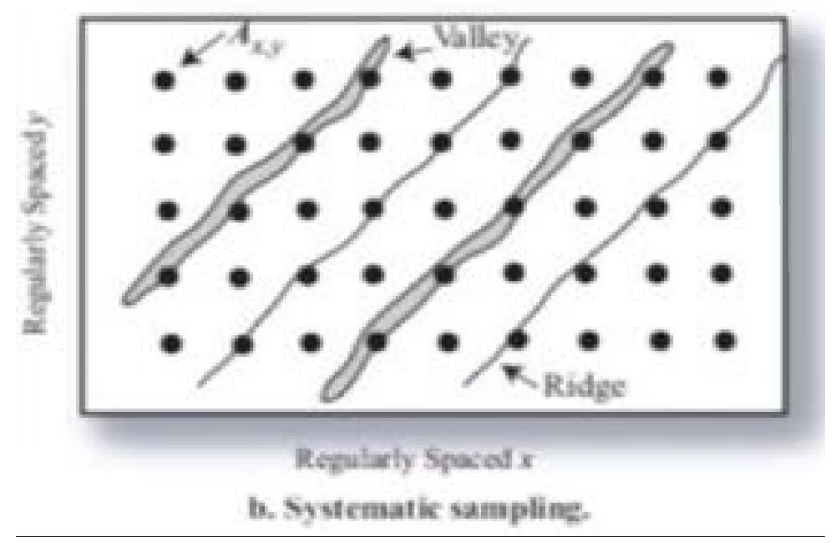


This study used a raster-based GIS analysis. Raster analysis makes it possible to analyze data in a continuous format and data grid. GIS analysis used were euclidean distance, top to raster, feature to raster, reclassify, slope, and masking. This study used logistic regression to predict the relationship of the dependent variable on a dichotomous scale. The dichotomy scale used a nominal data scale with two categories, for example: change and not change, good and bad, or high and low. The dependent variable used was the land-use change from forest to non-forest based on dynamic analysis of past land use. Ordinary linear regression requires the requirement or assumption that error variance (residual) is normally distributed. Conversely, this regression does not require these assumptions because logistic regression follows the logistical distribution. The logistic regression equation used is as follows:

$\log \left(Y_{i}\right)=\beta_{0}+\beta_{1} X_{1, i}+\beta_{2} X_{2, i}+\ldots+\beta_{n} X_{n, i}$ (Error! No text of specified style in document..1) Description:

$$
\begin{array}{ll}
\mathrm{Y}_{\mathrm{i}}=\text { Probability of forest conversion } \mathrm{i} & \mathrm{X}_{7}=\text { Distance from the settlement } \\
\mathrm{X}_{1}=\text { Distance from river } & \mathrm{X}_{8}=\text { Distance from road } \\
\mathrm{X}_{2}=\text { Rainfall } & \mathrm{X}_{9}=\text { Distance from government office } \\
\mathrm{X}_{3}=\text { Soil } & \mathrm{X}_{10}=\text { Distance from HTI } \\
\mathrm{X}_{4}=\text { Elevation } & \mathrm{X}_{11}=\text { Distance fromPalm Oil HGU } \\
& \mathrm{X}_{11}=\text { Distance from oil and gas well } \\
\mathrm{X}_{5}=\text { Slope } & \mathrm{X}_{12}=\text { The } 1986 \text { TGHK } \\
\mathrm{X}_{6}=\text { Total population } & \\
\beta_{0}=\text { Constants } & \\
\beta_{1-\mathrm{n}}= & 1^{\text {st }} \text { to } \mathrm{n} \text {-th independent variable coefficient } \\
\mathrm{X}_{1-\mathrm{n}, \mathrm{i}}= & 1^{\text {st }} \text { to } \mathrm{n} \text {-th independent variables on i dependent variable } \\
\mathrm{n} & =\text { Number of variables }
\end{array}
$$

Wald test is used to examine the effect of independent variables on the dependent variable partially. Wald test works by comparing the Wald statistical value with the Chi square comparative value at degrees of freedom $(\mathrm{db})=1$. In this test the authors used a significance value $(\rho)$ to determine whether or not the independent variable affects the dependent variable. If $\rho$-value is smaller than $\alpha$, it can be concluded that the independent variable can partially influence the dependent variable.

\section{RESULT AND DISCUSSION}

\section{Forest Area Spatial Planning Policybased on The 1986 TGHK}

Forest area spatial planning arrangement for Riau Province until 2014 was regulated in Decree of the Minister of Forestry Number 173 of 1986 on Forest Land Use Agreement (TGHK) Level I of Riau (SK 7651/2011 issued in 2011 mentioning that SK 173/1986 still applies). The 1986 TGHK includes the division of Spatial Use based on Forest Functions into 5 Classifications namely Protected Forest, Nature 
Reserve and Tourism Forest, Limited Production Forest, Permanent Production Forest, and Convertible Production Forest. In addition to the 5 classifications, there are 2 nonforestry function classifications namely Non-Forest Area (APL) and body of water.

The third point of SK.173/kpts-II/1986 instructs the Head of the Forest Inventory and Utilization Agency to carry out the measurement and arrangement of the forest area boundaries in the field but is not implemented in most forest areas in Riau Province. This has become one of the factors in violation of the 1986 TGHK. In addition, weak governance and oversight also contributed to the ineffectiveness of the 1986 TGHK in spatial planning so that many violations were found. Many of the areas designated as forest areas in The 1986 TGHK have been converted to land uses outside the forestry function. The 1986 TGHK established 97.8 percent of Riau Province as a forest area. For Rokan Block, 91\% of the Rokan Block area is a forest area such as Protected Forest, Nature Reserve and Tourism Forest, Production Forest, Convertible Production Forest, and Limited Production Forest as shown in Table 1 below.

Table1. Rokan Block Area Tabulation Based On The 1986 TGHK

\begin{tabular}{lrr}
\hline Area Status & Area (Ha) & Percentage (\%) \\
\hline Non-Forest Area & $54,130.00$ & $0.4 \%$ \\
Body of water & $2,666.69$ & $1.9 \%$ \\
Protected Forest (HL) & $12,191.40$ & $3.1 \%$ \\
Nature Reserve and Tourism Forest & $20,131.90$ & $32.8 \%$ \\
(HS) & & \\
Production Forest (HP) & $212,907.00$ & $21.7 \%$ \\
Limited Production Forest (HPT) & $141,044.00$ & $31.7 \%$ \\
Convertible Production Forest (HPK) & $206,041.00$ & $8.3 \%$ \\
\hline
\end{tabular}

\section{Land-use Change of Forestin 2000-2014 Rokan BlockForest Area in 2000}

Forest condition data in 2000 was obtained from Global Forest Change 20002018 data published by Hansen. The Global Forest Change project is a global forest monitoring program in collaboration with the University of Maryland, USA - USGS NASA and Google. The publication of this program was also published in the International Science Journal in $\left.2013,{ }^{9}\right]$ and is continually updated. Multitemporal Landsat remote sensing image analysis with a resolution of 30 meters was used to characterize the global forest area and change from 2000 to 2018. Hansen defined forests as vegetation cover with a minimum height of 5 meters with a minimum canopy cover of 30 percent. Hansen et al. conducted several improvements to the quality of input data before the data was classified. $\left[{ }^{9}\right]$

In addition, several processes such as:

a. Detection of forest loss due to fire;

b. Detection of smallholder rotational agriculture in tropical forests;

c. Detection of selective logging;

d. Detection of short cycle plantations in subtropical and tropical zones. 
Hansen et al. $\left[^{9}\right]$ classified forest data and its changes in a multi-temporal manner. The distribution of forest in Rokan Block in 2000 that will be used for the study needs to be converted into dummy data (coding of variables to 0 and 1), as in Figure 1 below.

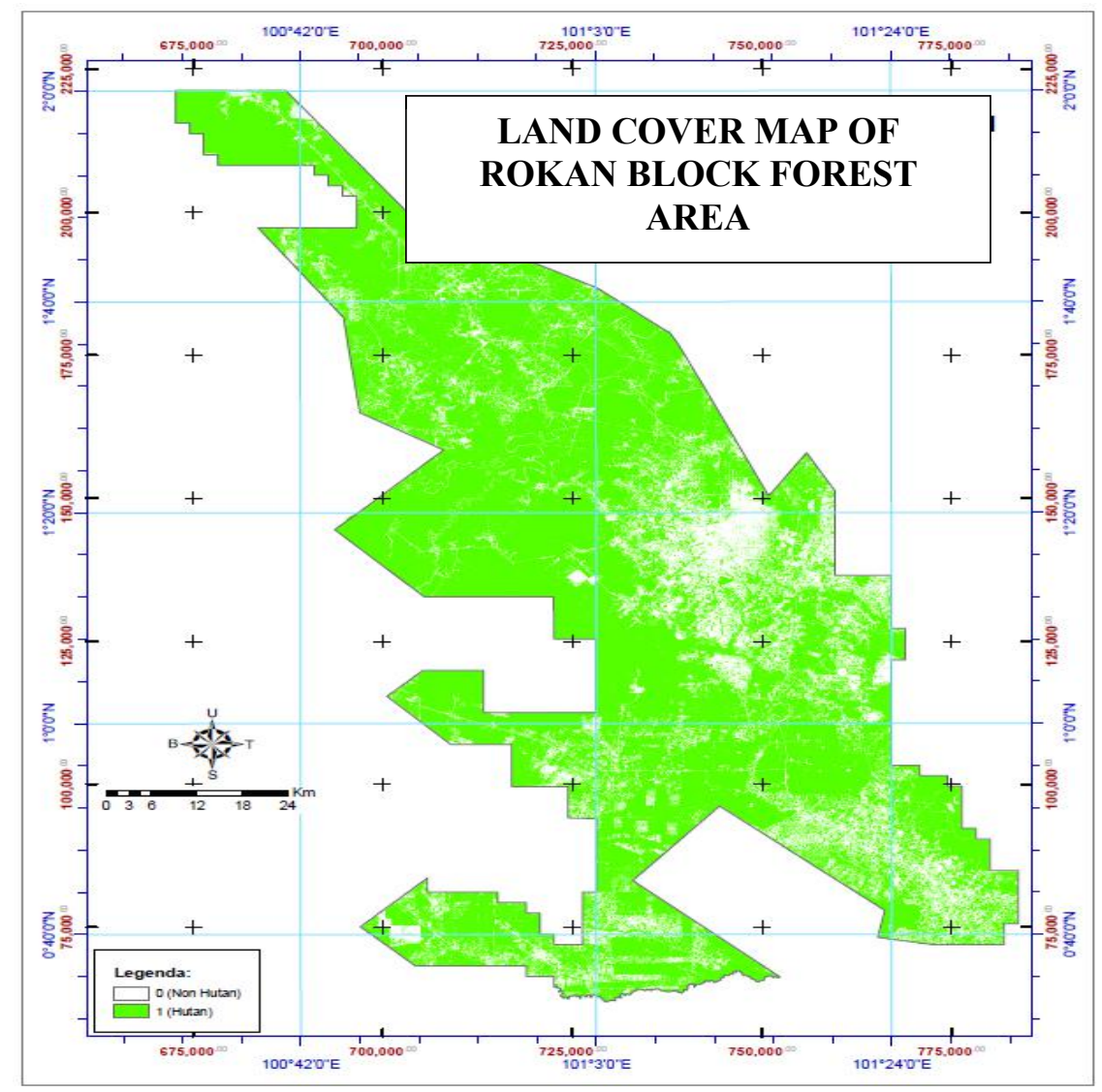

Figure 1. Land Cover Map of Rokan BlockForest Area in 2000 (Dummy)

The forest area in Rokan Block in 2000 as a dummy result was 521 thousand hectares (5.8 million pixels) or around 80 percent of Rokan Block. The 80 percent forest area is a sizeable proportion compared to the non-forest area which is only about 20 percent as shown in Table 2 . When compared to the 1986 TGHK plan, the forest area in Rokan Block was 91 percent, so that in 2000 there was a difference forest area of around 11 percent.

Table. 2. Tabulation of Forest and Non-Forest inRokan Block as Dummy Result

\begin{tabular}{clrrr}
\hline Dummy Code & Land Use & Total Pixel & Area (Ha) & $\begin{array}{r}\text { Percentage } \\
(\mathbf{\%})\end{array}$ \\
\hline 0 & Non Forest & $1,421,444.00$ & $127,929.96$ & 20 \\
1 & Forest & $5,790,528.00$ & $521,147.52$ & 80 \\
\hline
\end{tabular}

\section{Forest Conversion in 2000-2014}

The data source used to see the forest conversion in 2000-2014 was dummy analysis of Global Forest Change data from 2000-2014. Forest loss was defined as a disturbance in the replacement of stands or changes from forest to non-forest 
conditions. The description of forest conversion in 2000-2014 occurred over a large area as can be seen in Figure 2 below.

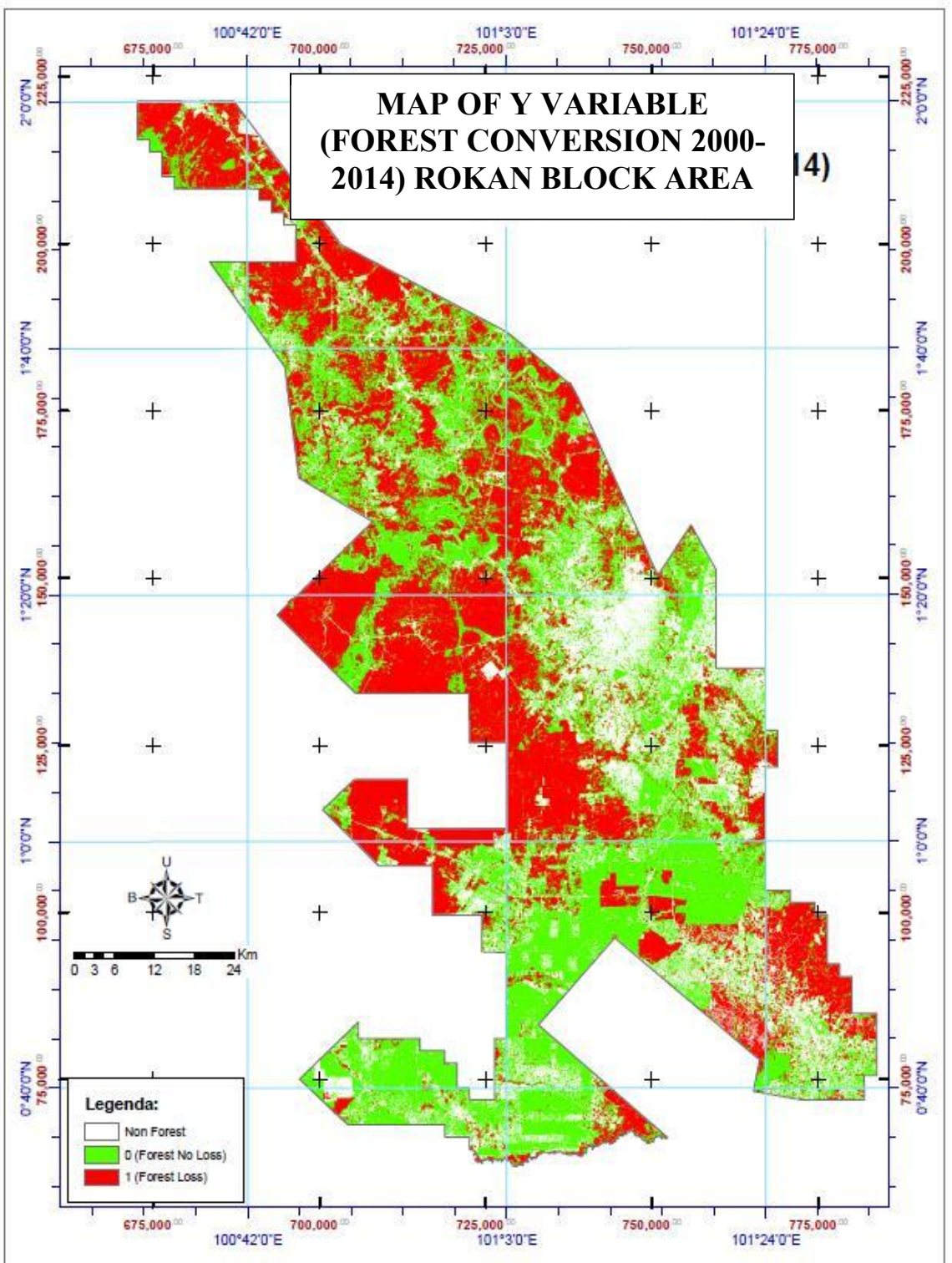

Figure 2. Forest conversionmap of Rokan Block Area in 2000-2014

The red color in Figure 2 shows the converted forest in 2000-2014. It can be seen that forest land conversion occured in almost every part of Rokan Block with the majority in the central and northern parts of Rokan Block. The tabulated conversion of forests from 2000 to 2014 was around 248 thousand hectares $(2.7$ million pixels $)$. This conversion made the forest land use cover in Rokan Block decreased dramatically from 80 percent in 2000 to 42 percent in 2014 as shown in Table 3. 
Table 3. Tabulation of Dummy Analysis of Forest Conversionin 2000-2014

\begin{tabular}{clrcc}
\hline Dummy Code & $\begin{array}{l}\text { Forest } \\
\text { Conversion }\end{array}$ & Total Pixel & Area (Ha) & $\begin{array}{c}\text { Percentage } \\
\text { (\%) }\end{array}$ \\
\hline- & Non Forest & $1.421 .444,00$ & $127.929,96$ & 20 \\
0 & Forest (No Loss) & $3.023 .251,00$ & $272.092,59$ & 42 \\
1 & Forest (Loss) & $2.763 .150,00$ & $248.683,50$ & 38 \\
\hline
\end{tabular}

Margono [ $\left.{ }^{9}\right]$ stated that in this period, Riau experienced the largest forest conversion in the world. The period above 2000 is the period after the regional autonomy policy recommended through Resolution of MPR RI Number IV/MPR/2000 on Policy Recommendations in the Implementation of Regional Autonomy. Many people assume that the implementation of regional autonomy policy also influences forest conversion.

\section{Influencing factors of forest conversion}

The results of Wald Test showed that almost all independent variables $\mathrm{X}$ had a significant influence on the dependent variable $\mathrm{Y}$ with Sig. $<0.05$, except for two variables namely $\mathrm{X}_{6}$ (Total Population) and $\mathrm{X}_{13}$ (The 1986 TGHK) with sig $\geq 0.05$, which showed that both variables had no significant influence on forest conversion as in Table 4 below.

Table Error! No text of specified style in document.. Wald Test Results in Rokan Block

\begin{tabular}{|c|c|c|c|c|c|c|c|c|c|}
\hline \multicolumn{10}{|c|}{ Variables in the Equation } \\
\hline & & \multirow[b]{2}{*}{ B } & \multirow[b]{2}{*}{ S.E. } & \multirow[b]{2}{*}{ Wald } & \multirow[b]{2}{*}{ df } & \multirow[b]{2}{*}{ Sig. } & \multirow[b]{2}{*}{$\operatorname{Exp}(B)$} & \multicolumn{2}{|c|}{ 95\% C.I.for EXP(B) } \\
\hline & & & & & & & & Lower & Upper \\
\hline \multirow[t]{14}{*}{ Step $1^{\mathrm{a}}$} & X1_Jarak_Sungai & -0.000020 & 0.000006 & 10.189670 & 1.000000 & 0.001412 & 0.999980 & 0.999967 & 0.999992 \\
\hline & X2_Hujan & 0.000389 & 0.000130 & 8.903082 & 1.000000 & 0.002847 & 1.000389 & 1.000133 & 1.000645 \\
\hline & X3d1_Tanah_Mineral(1) & 0.641416 & 0.076117 & 71.009230 & 1.000000 & 0.000000 & 1.899169 & 1.635960 & 2.204726 \\
\hline & X4_Elevasi & -0.013467 & 0.003356 & 16.099181 & 1.000000 & 0.000060 & 0.986623 & 0.980154 & 0.993135 \\
\hline & X5_Lereng & 0.090797 & 0.015255 & 35.427029 & 1.000000 & 0.000000 & 1.095047 & 1.062791 & 1.128282 \\
\hline & X6_Jml_Penduduk & -0.000008 & 0.000007 & 1.459824 & 1.000000 & 0.226958 & 0.999992 & 0.999978 & 1.000005 \\
\hline & X7_Jarak_Permukiman & 0.000210 & 0.000016 & 165.772405 & 1.000000 & 0.000000 & 1.000210 & 1.000178 & 1.000243 \\
\hline & X8_Jarak_Jalan & -0.000196 & 0.000076 & 6.601270 & 1.000000 & 0.010191 & 0.999804 & 0.999654 & 0.999953 \\
\hline & X9_Jarak_Pemerintah & 0.000049 & 0.000007 & 45.446789 & 1.000000 & 0.000000 & 1.000049 & 1.000035 & 1.000064 \\
\hline & X10_Jarak_HTI & -0.000048 & 0.000008 & 37.058303 & 1.000000 & 0.000000 & 0.999952 & 0.999936 & 0.999967 \\
\hline & X11_Jarak_HGU & 0.000050 & 0.000007 & 53.315087 & 1.000000 & 0.000000 & 1.000050 & 1.000036 & 1.000063 \\
\hline & X12_2014_Jarak_Sumur & -0.000046 & 0.000017 & 7.311791 & 1.000000 & 0.006850 & 0.999954 & 0.999920 & 0.999987 \\
\hline & X13d1_TGHK_Forest(1) & 0.038064 & 0.145157 & 0.068762 & 1.000000 & 0.793148 & 1.038798 & 0.781579 & 1.380668 \\
\hline & Constant & -1.548749 & 0.223324 & 48.094064 & 1.000000 & 0.000000 & 0.212514 & & \\
\hline
\end{tabular}


The proportion of contributions to Rokan Block was performed on variables that have been known to influence the previous analysis. The proportion of contributions was performed with 3 testing groups. The first group was conducted on biophysical component variables namely: distance from river $\left(\mathrm{X}_{1}\right)$, rainfall $\left(\mathrm{X}_{2}\right)$, type of soil $\left(\mathrm{X}_{3}\right)$, elevation $\left(\mathrm{X}_{4}\right)$ and slope $\left(\mathrm{X}_{5}\right)$. The second group was performed on social variables: distance from settlement $\left(\mathrm{X}_{7}\right)$, distance from road $\left(\mathrm{X}_{8}\right)$ and distance from government office $\left(\mathrm{X}_{9}\right)$.The third group was performed on economic variables : distance from HTI $\left(\mathrm{X}_{10}\right)$, distance from $\mathrm{HGU}\left(\mathrm{X}_{11}\right)$, and distance from oil and gas well $\left(\mathrm{X}_{12}\right)$.

The teston the biophysical variable group showed that the type of soil (X3) was the most influential variable and contributed significantly to the increase in R-Square with a high proportion of increase. Meanwhile, the contribution of other variables respectively was slope (X5), elevation (X4), rainfall (X2), and distance from the river (X1), as shown in Figure 3 below.

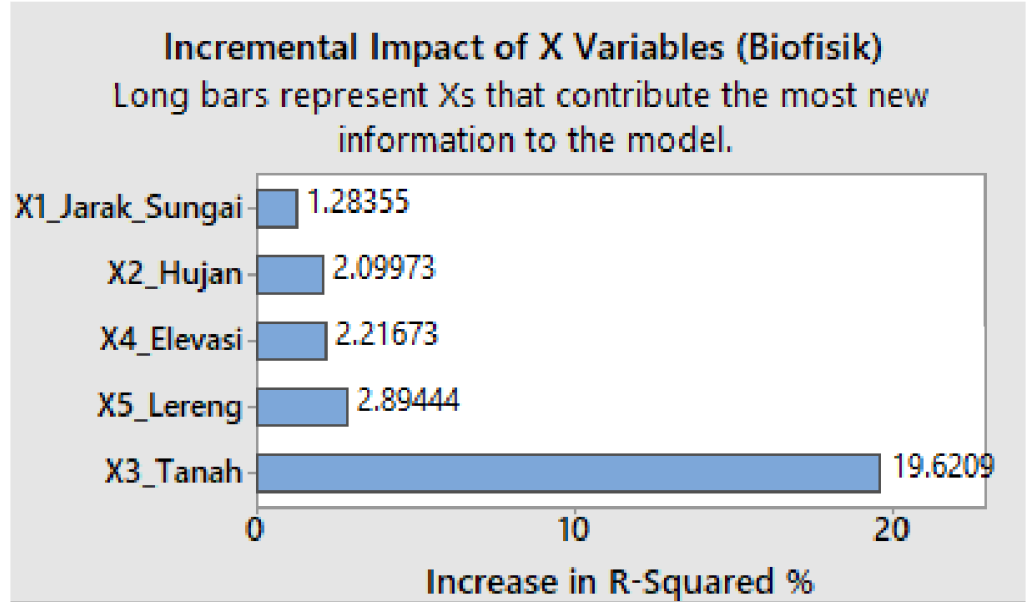

Figure 3. Proportion of Contributions of Biophysical Component Variables

The test on the social variable group showed that distance from settlement (X7) was the most influential variable and contributed significantly to the increase in RSquare with a high proportion of increase. Meanwhile, the contribution of other variables respectively was distance from government office (X9) anddistance from road (X8) as shown in Figure 4 below.

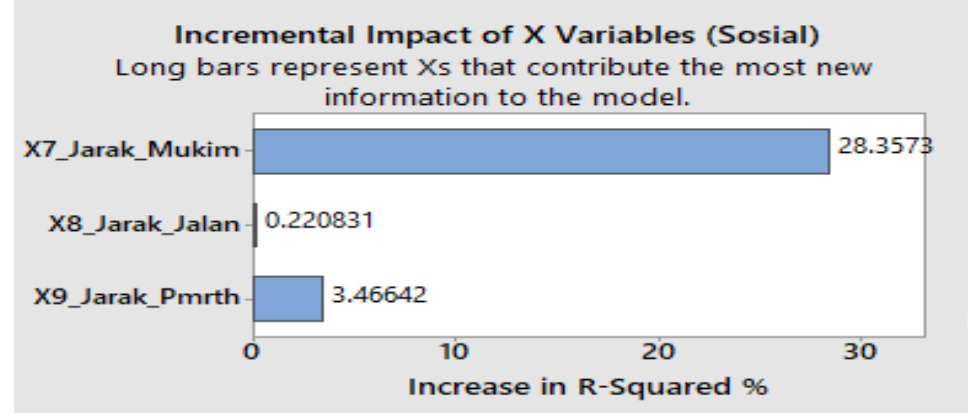

Figure Error! No text of specified style in document.. Proportion of Contributions of Social Component Variables 
The test on the economy variable group showed the distance from HGU (X11) which contributed significantly to the increase in R-Square with a proportion of an increase of almost $15 \%$. Meanwhile, distance from oil and gas well (X12) made the smallest contribution between HGU (X11) and HTI (X10), as shown in Figure 5.

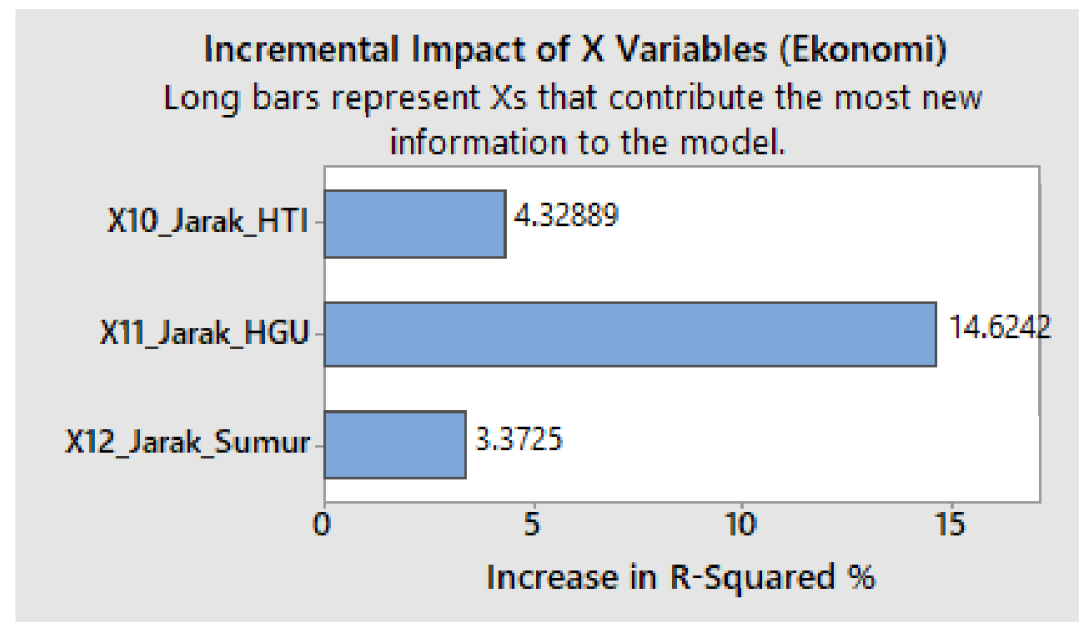

Figure5. Proportion of Contributions of Economy Component Variables

\section{CONCLUSION}

Rokan Block Area experienced a pretty bad forest conversion in 2000-2014. During this period, forest cover in Rokan Block declined dramatically from 80 percent in 2000 to 42 percent in 2014.

Forest conversionwas significantly influenced bydistance from river, rainfall, type of soil, elevation, slope, distance from settlement, distance from road, distance form government office, distance from HTI, distance from HGU, and distance fromoil and gas well, while total populationand The 1986 TGHKhad no significant influence onforest conversioninRokan Block.The insignificant of the 1986 TGHK showed weak governance and implementation of spatial planning policies that caused forest conversion to be out of control in 2000-2014.

Forest conversion practitioners prefer forests on mineral soils as a priority because of easy access. The active role of communities around the forests that still uphold the concern for the forest must be preserved, because they will be the front guard in securing forest encroachment, and oil and gas are not the main economic activities that cause forest conversion.

\section{ACKNOWLEDGMENTS}

We would like to express my gratitude to Universitas Riau and PT.Chevron Pacific Indonesia for the assistance so that this research could be carried out. 


\section{REFERENCES}

(1) Maulana, H. SKK Migas: Indonesia Tidak Lagi Negara Kaya Minyak Bumi dan Gas https://regional.kompas.com/read/2017/11/02/11192211/skk-migas-indonesia-tidaklagi-negara-kaya-minyak-bumi-dan-gas (accessed Sep 1, 2020).

(2) Widayati, R. Kinerja Sektor Migas di Riau Meningkat 5 Tahun Terakhir https://bisnis.tempo.co/read/829658/kinerja-sektor-migas-di-riau-meningkat-5-tahunterakhir (accessed Sep 1, 2020).

(3) Harun, J. Permasalahan Minyak dan Gas (Migas) di Riau. J. Ekon. Univ. Riau 2009, $17(03), 8772$.

(4) Wirawan; Hidayatsyah. Laporan Penyelesaian Status BMN Tanah CPI Yang Berada Di Kawasan Hutan. 2016.

(5) McNeil. Toward a Typology and Regionalization of Land Cover and Land Use Change; Press Syndicate of The University of Cambridge: Cambridge, 1998.

(6) Nugroho, I.; Dahuri, R. Pembangunan wilayah: perspektif ekonomi, sosial, dan lingkungan; LP3ES, 2004.

(7) Lillesand, T. M.; Kiefer, R. W.; Chipman, J. W. Remote Sensing and Image Interpretation; Wiley, 2004.

(8) Jensen, J. R. Introductory Digital Image Processing: A Remote Sensing Perspective; Pearson Education, Incorporated, 2016.

(9) Margono, B. A.; Potapov, P. V.; Turubanova, S.; Stolle, F.; Hansen, M. C. Primary Forest Cover Loss in Indonesia over 2000-2012. Nat. Clim. Change 2014, 4 (8), 730735. https://doi.org/10.1038/nclimate2277. 